\title{
The Use of Rubber Leaves (Hevea brasiliensis) as Forage in Supporting the Development of Goats
}

\author{
Wigati S, Maksudi, Wiyanto E \\ Faculty of Animal Science, Jambi University \\ Jl. Jambi-Muara Bulian Km 15, Mendalo Darat, Jambi, Indonesia \\ sriwigati@unja.ac.id
}

\begin{abstract}
The nutritive potency of rubber leaves (Hevea brasiliensis) as forage/feed for goats was analysed in vivo. Twenty four male and female postweaned Etawah grade kids aged 4-6 months with body weights between 11 to $26 \mathrm{~kg}$ were allocated into three treatment groups (i.e. T0, T1 and T2) with eight repetition designed as Randomized Block Design. Treatment diet T0 consisted of $0 \%$ rubber leaves, $80 \%$ other forages and $20 \%$ rice bran. Treatment diet $\mathrm{T} 1$ consisted of $40 \%$ rubber leaves, $40 \%$ other forages and $20 \%$ rice bran, and Treatment diet T2 consisted of $60 \%$ rubber leaves, $20 \%$ other forages and $20 \%$ rice bran. The results showed that DM, DE and DP consumptions, ADG and FCR of the T0, T1 and T2 treatment groups were respectively: 1008, 1040 and $1199 \mathrm{~g} \mathrm{DM}$; 2.8, 2.9 and 4.0 McalDE; 31.9, 42.9 and 59.8 g DP; 58.2, 85.7 and 76.1 $\mathrm{g} / \mathrm{head} /$ day; 25.6, 15.9 and 18.0. It can be concluded that the use of rubber leaves and its branches with composition of 40 to $60 \%$ of goat diets can increase energy and protein consumptions, increase body weight gain, decrease FCR, and subsequently increase the production efficiency of the goats.
\end{abstract}

Key Words: Rubber Leaves, Hevea brasiliensis, Herbal Nutrition, Goat, Digestible Protein

\section{INTRODUCTION}

The exploration of rubber leaves (Hevea brasiliensis) as a source of animal feedstuff is a strategic issue in supporting the development of rural goat farming, especially those integrated into rural community rubber plantations. Rubber leaves and branches used as forage are harvested from the wild rubber trees growing under the main rubber trees. Analysis of rubber leaf potency as herbal nutrition (nutritive herbs) for goats had been previously carried out by quantitatively analysing the chemical composition of the feed, the content of total tannins and condensed tannins of fresh and 1d-withered leaves and branches (edible portion) of rubber trees taken from 7 types of rubber tree clones. The chemical composition of fresh rubber leaves were: 40.4\% DM; $87.9 \% \mathrm{OM} ; 19.5 \% \mathrm{CP}$; $6.2 \% \mathrm{EE}$ and $27.0 \% \mathrm{CF}$, and of withered rubber leaves were: $42.1 \% \mathrm{DM} ; 89.5 \% \mathrm{OM}$; $21.19 \% \mathrm{CP} ; 5.2 \% \mathrm{EE}$ and $25.9 \% \mathrm{CF}$. Branches part of fresh rubber had a lower quality than the leaves part of fresh rubber. Whithering of rubber leaves during the day can increase its quality (Wigati et al. 2014a). Average total tannins content in the fresh rubber leaves and branches (DM base) was $2.71 \%$, and of the withered form was $2.37 \%$. Average content of condensed tannins in the fresh rubber leaves and branches was $2.05 \%$, and of the withered form was $2.52 \%$. Withering have lowered the content of total tannins, but relatively increased the content of condensed tannins. The contents of total tannins and condensed tannins in fresh or withered leaves and branches were indicated as nutritive levels. According to Makkar (2003), tannins within certain limits (2 to 4\% DM basis) can improve the efficiency of microbial protein synthesis and degradation and can protect the protein in the rumen, thereby increasing the flow of essential amino acids to the small intestine and increase the absorption of amino acid into the blood which in turn will be able to increase the productivity of livestock. In ruminants, tannin, particularly condensed tannin has been reported to have an effect as a medicinal herb, which is as anti-parasitic 
gastro-intestinal (natural anthelmintic) as reported by Paolini et al. (2003). The results of the previous research showed that rubber leaves and branches have good feeding value for goats, can be used in both fresh and withered form, and also indicated a potency as herbal medicine for goats (Wigati et al. 2014a). Further exploration of herbal nutrition potencies of rubber leaves and its branches by in sacco analysis in the previous research (Wigati et al. 2015) showed that rubber leaves and its branches (edible portion) have high protein contents, but relatively low energy contents. The average values of UDP and ME contents in fresh rubber leaves and branches were $40.88 \%$ and $8.07 \mathrm{MJ} \mathrm{ME} / \mathrm{Kg} \mathrm{DM}$, and in $1 \mathrm{~d}$ withered form were $37.15 \%$ and $8.09 \mathrm{MJ} \mathrm{ME} / \mathrm{Kg} \mathrm{DM}$. Moreover, the results of in vitro analysis of herbal potency of rubber leaves and its branches showed that the tannins contained in rubber leaves and its branches at a concentration of $\geq 2 \mathrm{~g}$ tannins $(3.5 \%$ dry weight basis) has a strong anthelmintic effect against adult female Haemonchus contortus worms (Wigati et al. 2015). However, the nutritive and herbal effects of rubber leaves and its branches fed directly to goats have not been studied. Hence, the research was carried out to evaluate the nutritive effects of rubber leaves and its branches in vivo on energy and protein digestibilities and performace of postweaned Etawwah Grade kids.

\section{MATERIAL AND METHODS}

The research was carried out in a rural community goat farming in a region of Jambi Province, Indonesia. The experiment used 24 male and female postweaned Etawah grade kids aged 4-6 months with body weights between 11 to $26 \mathrm{~kg}$. The forages used as treatment diets were edible portion (parts of rubber tree which can be consumed by the animal) of fresh rubber leaves and its branches taken from the area of rubber plantation (Figure 1), and other forages used were grasses (Otochloa nodosa, Axonopus compresus) and browsed plants/weeds such as cabe-cabean (Asystasia gangetica), anggrung putih (Trema orientalis) and Gusduran (Mikania micrantha). Botanical parts of other forages used were leaves and branches of the plants. The concentrate used was rice bran. Feed chemical composition of the feed samples were determined by using proximate analysis procedure according to AOAC (2002).
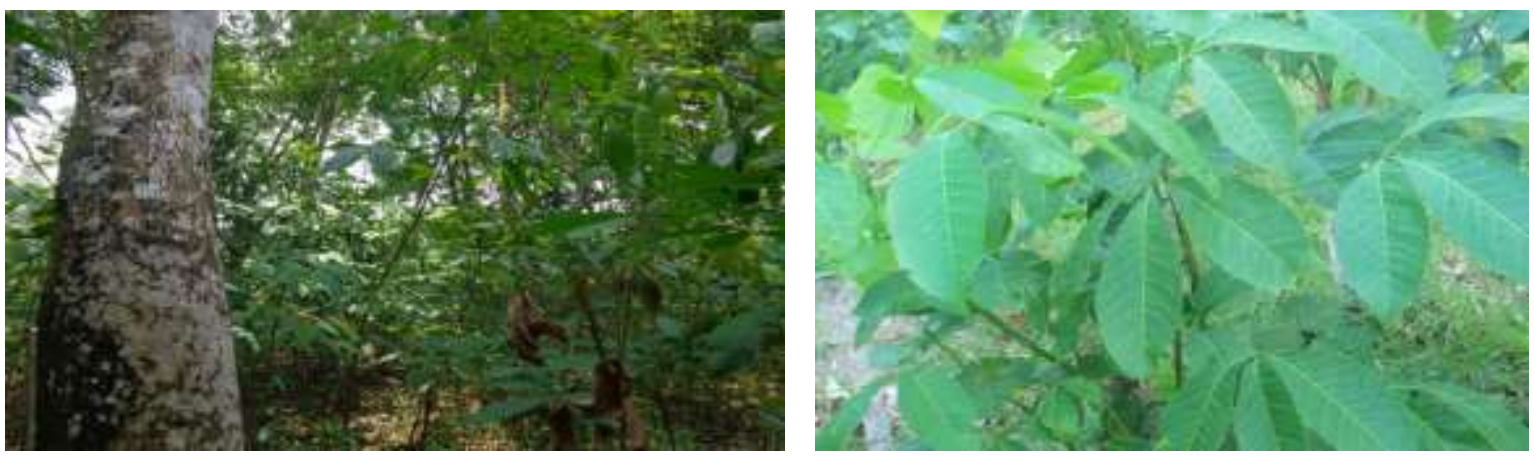

Figure 1. Rubber trees (Hevea brasiliensis) and rubber leaves and its branches

Each of experimental animals was placed in an individual stable and was allocated into three treatment groups (i.e. T0, T1 and T2) given three treatment diets. The treatment diets used were $\mathrm{T} 0, \mathrm{~T} 1$ and $\mathrm{T} 2$ which the compositition were

$\mathrm{T} 0=0 \%$ rubber leaves and its branches $+80 \%$ other forages $+20 \%$ rice bran

$\mathrm{T} 1=40 \%$ rubber leaves and its branches $+40 \%$ other forages $+20 \%$ rice bran

$\mathrm{T} 2=60 \%$ rubber leaves and its branches $+20 \%$ other forages $+20 \%$ rice bran

The feed chemical composition of the trial diets was presented in Table 1. 
Tabel 1. Feed chemical composition of the treatment diets

\begin{tabular}{lrrr}
\hline \hline \multirow{2}{*}{ Composition (\%) } & \multicolumn{3}{c}{ Treatment diets } \\
\cline { 2 - 4 } & \multicolumn{1}{c}{ T0 } & \multicolumn{1}{c}{ T2 } \\
\hline Dry matter (DM) & 32.43 & 37.42 & 39.91 \\
Organic matter (OM) & 90.14 & 92.54 & 93.80 \\
Crude protein (CP) & 13.40 & 15.43 & 16.39 \\
Extract ether (EE) & 3.75 & 3.94 & 4.03 \\
Crude fibre (CF) & 17.77 & 18.58 & 19.00 \\
Nitrogen free extract (NFE) & 55.24 & 54.26 & 53.88 \\
Total digestible nutrients (TDN) & 76.10 & 77.40 & 87.60 \\
\hline
\end{tabular}

$\mathrm{T} 0=0 \%$ rubber leaves and its branches $+80 \%$ other forages $+20 \%$ rice bran; $\mathrm{T} 1=40 \%$ rubber leaves and its branches $+40 \%$ other forages $+20 \%$ rice bran ; $22=60 \%$ rubber leaves and its branches $+20 \%$ other forages $+20 \%$ rice bran. Feed chemical composition of the trial diets was calculated by using feed chemical composition of each feedstuff used in the trial diets analysed in preliminary research

The feed quantities given to the goats were determined based on DM intake of Bligon goats, i.e. 3.5\% of body weight, according to Wigati (2010). The feeding trial was carried out for 6 weeks with 2 weeks adaptation before feeding trial commenced. Treatment diets were given twice a day (in the morning and the afternoon), and were provided which enabled animals to choose freely (free choice). Drinking water was given in separated tin and was given ad libitum. The individual stable was equipped with a net for feces collection. The collections of the feeds, feed left overs and feces were carried out for 7 days in the end week of the feeding trial. Samples collected were oven-dried at a temperature of $55^{\circ} \mathrm{C}$, grinded and analysed for feed/feces chemical composition using proximate analysis (AOAC 2002). Kids were weighed at 7 days interval.

Experimental Design. The kids were allocated into three treatment groups (T0, T1 and T2), and were designed in Randomized Block Design (RBD) based on sex and body weight. Each treatment group consisted of 8 goats as replication. Variables observed from feeding trials were dry matter (DM), digestible energy (DE) and digestible protein (DP) consumptions, ADG of the kids and feed conversion ratio (FCR).

Statistical Analysis. Data was analyzed by Analysis of variance (ANOVA) using General Linear Model (GLM) procedures. Any significant differences between treatments will be tested using the LSD-test (SPSS 16.0).

\section{RESULTS AND DISCUSSION}

\section{Feed chemical composition of the feedstuffs used as treatment diets}

From the preliminary research, it can be identified that forages or browse feeds other than rubber leaves that were most frequently and usually used by local farmer were rumput paitan (Axonopus compresus), rumput kawatan (Otochloa nodosa), and browse feed/weeds which were grown under the shade of rubber trees, such as cabe-cabean (Asystasia gangetica), anggrung puth (Trema orientalis) and Gusduran (Mikania micrantha). Feed Chemical Compositions of the feedstuffs used as treatment diets collected during feed collection were presented in Table 2.

The results of proximate analysis of the feedstuffs used in the research showed a decrease in quality from the midle to the end of the feeding trial. During the time (half end of feeding trial), it was also difficult to provide other forages other than rubber leaves. The 
condition was due to a long dry season, and very bad air quality at that period due to forest fires.

Table 2. Feed chemical compositions of the feedstuffs used as treatment diets

\begin{tabular}{lcccccc}
\hline \hline \multirow{2}{*}{ Forages } & DM & OM & CP & EE & CF & NFE \\
\cline { 2 - 7 } & $\ldots \ldots \ldots \ldots \ldots \ldots \ldots \ldots \ldots \ldots \ldots \ldots \ldots \ldots \ldots \ldots \ldots \ldots \ldots \ldots \ldots \ldots \ldots \ldots \ldots \ldots \ldots \ldots \ldots \ldots \ldots \ldots \ldots \ldots \ldots \ldots \ldots \ldots$ \\
\hline Hevea brasiliensis & 39.12 & 95.95 & 18.43 & 3.68 & 20.95 & 52.07 \\
Axonopus compresus & 38.30 & 93.00 & 9.05 & 0.76 & 21.80 & 61.38 \\
Otochloa nodosa & 36.05 & 92.16 & 11.58 & 3.34 & 22.42 & 54.84 \\
Asystasia gangetica & 22.55 & 87.26 & 16.29 & 3.62 & 17.41 & 49.94 \\
Trema orientalis & 31.96 & 89.29 & 14.14 & 4.69 & 15.30 & 55.16 \\
Mikania micrantha & 22.43 & 90.81 & 12.61 & 3.92 & 17.58 & 56.70 \\
Rice bran & 89.35 & 90.90 & 13.65 & 5.93 & 13.15 & 58.17 \\
\hline
\end{tabular}

\section{The consumption of dry matter in the diets}

Table 3 presents dry matter (DM) consumption of the treatment diets and dry matter intake (DMI) in the kids with an average body weights of $21.7 \mathrm{~kg}$ in T0 group, $23.5 \mathrm{~kg}$ in $\mathrm{T} 1$ group and $21.2 \mathrm{~kg}$ in $\mathrm{T} 2$ group (Figure 2).

Table 3. The average values ( \pm SEM) of dry matter $(\mathrm{DM})$ consumptions and dry matter intakes (DMI) of the kids during the feeding trial

\begin{tabular}{lccc}
\hline \hline \multirow{2}{*}{ Variables } & \multicolumn{3}{c}{ Treatment Diets } \\
\cline { 2 - 4 } & T0 & T1 & T2 \\
\hline DM consumption (g/head/day) & $1008^{\mathrm{a}} \pm 47.1$ & $1040^{\mathrm{ab}} \pm 73.2$ & $1199^{\mathbf{b}} \pm 63.3$ \\
DMI (\% BW) & $4.9 \pm 0.4$ & $4.9 \pm 0.8$ & $5.9 \pm 0.5$ \\
\hline
\end{tabular}

$\mathrm{T} 0=0 \%$ rubber leaves and its branches $+80 \%$ other forages $+20 \%$ rice bran; $\mathrm{T} 1=40 \%$ rubber leaves and its branches $+40 \%$ other forages $+20 \%$ rice bran; $\mathrm{T} 2=60 \%$ rubber leaves and its branches $+20 \%$ other forages $+20 \%$ rice bran. Different superscripts in the same row showed significant differences $(\mathrm{P}<0.05)$. SEM: Standard Error Means

The statistical analysis showed that DM consumption in T1 treatment group was not significantly different $(\mathrm{P}>0.05)$ with those of $\mathrm{T} 0$ and $\mathrm{T} 2$ treatment groups $(\mathrm{P} \geq 0.09)$, but $\mathrm{DM}$ consumption in $\mathrm{T} 2$ treatment group was significantly different $(\mathrm{P}<0.05)$ with that of T0 treatment group. Since rubber leaves forage has a higher DM and crude protein (CP) contents than other forages (Table 2), it was concluded that higher DM consumption in T2 was due to a higher rubber leaves content in $\mathrm{T} 2$ treatment diet.
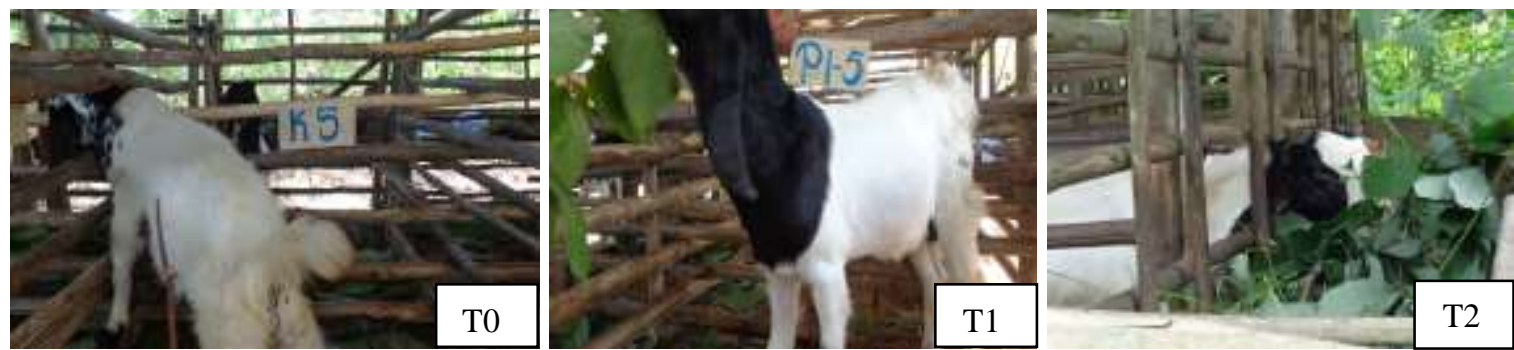

Figure 2. The goat kid in each treatment group 
DMI $(\% \mathrm{BW})$ was not significantly different $(\mathrm{P}>0.05)$ between treatment groups. Dry matter consumptions in all treatment groups were high according to the DMI values. DMI value in $\mathrm{T} 2$ treatment group was higher than that of Bligon kids fed with King grass as basal feed (Wigati 2010), i.e. 2,8 \% of body weight, and was also higher than that of Bligon does fed Timor savannah grass suplemented with Urea Gula Air Multinutrient Block (Manu et al. 2015), i.e. 3.0\% of body weight. The high DMI in kids fed with high proportion of rubber leaves was could also be due to high protein content of rubber leaves (Wigati et al. 2014; 2015). Acording to Aregheore (2003), total DMI increase with the increase of protein content in the diet, and Mohsen et al. (2011) also stated that a better nutrients digestibility will increase nutrient intakes. Wigati et al. (2015) has previously reported that rubber leaves and its branches had high crude protein contents $(20.21 \%$ in average) and high protein digestibility by in sacco analysis $(59.12 \%$ protein degradability and $40.88 \%$ undegraded dietary protein).

\section{Digestible energy and digestible protein consumption}

Digestible energy and digestible protein consumptions of the kids during the feeding trial is presented in Table 4.

Table 4. The average values ( \pm SEM) of digestible energy (DE) and digestible protein (DP) consumptions of the kids during the feeding trial

\begin{tabular}{lrrr}
\hline \hline \multirow{2}{*}{ Variables } & \multicolumn{3}{c}{ Treatment diets } \\
\cline { 2 - 4 } & \multicolumn{1}{c}{$\mathrm{T} 0$} & \multicolumn{1}{c}{$\mathrm{T} 1$} & \multicolumn{1}{c}{$\mathrm{T} 2$} \\
\hline DE consumption (Mcal/head/day) & $2.8^{\mathbf{a}} \pm 0.2$ & $2.9^{\mathbf{a}} \pm 0.4$ & $4.0^{\mathbf{b}} \pm 0.2$ \\
DP consumption (g/head/day) & $31.9^{\mathbf{A}} \pm 1.7$ & $42.9^{\mathbf{B}} \pm 2.5$ & $59.8^{\mathbf{C}} \pm 2.6$ \\
\hline
\end{tabular}

$\mathrm{T} 0=0 \%$ rubber leaves and its branches $+80 \%$ other forages $+20 \%$ rice bran; $\mathrm{T} 1=40 \%$ rubber leaves and its branches $+40 \%$ other forages $+20 \%$ rice bran; $\mathrm{T} 2=60 \%$ rubber leaves and its branches $+20 \%$ other forages $+20 \%$ rice bran. Different lower case superscripts in the same row showed significant differences $(\mathrm{P}<0.05)$; Different upper case superscripts in the same row showed highly significant differences $(\mathrm{P}<0.01)$. SEM: standard error means

The results of statistical analysis showed that the digestible energy (DE) consumption in $\mathrm{T} 1$ treatment group was not significantly different $(\mathrm{P}>0.05)$ with that of T0 treatment group, but it was significantly different $(\mathrm{P}<0.05)$ with that of $\mathrm{T} 2$ treatment group. $\mathrm{DE}$ consumption in $\mathrm{T} 2$ was significantly higher $(\mathrm{P}<0.05)$ than that of $\mathrm{T} 0$ and $\mathrm{T} 1$. Meanwhile, the digestible protein (DP) consumptions were significantly different $(\mathrm{P}<0.01)$ between treatments. DP consumption in T0 treatment group was significantly lowest than those of treatment groups, and DP consumption in T1 treatment group was significantly lower than that of $\mathrm{T} 2$ treatment group.

According to NRC (1981), the DE for maintenance and $50 \mathrm{~g}$ average daily gain (ADG) in kids with body weights between 20 to $30 \mathrm{~kg}$ was $2.35-2.87 \mathrm{Mcal}$, and the DP 52 to $63 \mathrm{~g}$. Meanwhile, according to Kearl (1982), the DE need was 1.61 to $1.83 \mathrm{Mcal}$, and the DP need was 38 to $43 \mathrm{~g}$. The results of this experiment showed that DE consumptions in all treatment groups (T0, T1 and $\mathrm{T} 2$ ) have met the need of DE for maintenance and $50 \mathrm{~g}$ ADG according to NRC (1981) and Kearl (1982). The addition of rice bran concentrate as much as $20 \%$ of the total diets was suggested to have a contribution in meeting the energy needs in all treatment groups. Furthermore, in this experiment, most of rice bran offered to the animals was consumed, and rice bran has a high energy content, i.e. $10.15 \mathrm{MJ} / \mathrm{kg} \mathrm{DM}$ as reported by Wigati et al. (2014b). The results of this experiment also showed that DP 
consumption in $\mathrm{T} 1$ and $\mathrm{T} 2$ treatment groups have met the DP need for maintenance and 50 g ADG (NRC 1981; Kearl 1982), but it has not met the DP need yet in T0 treatment group according to both NRC (1981) and Kearl (1982). Hence, it can be concluded that the use of rubber leaves as a goat forage (feedstuff) can increase energy and protein consumptions in postweaning kids.

\section{Body weight gain and feed conversion ratio (FCR)}

Average daily body weight gain or average daily gain (ADG) is a factor that can significantly measure the growth of the animals. For most of the animals, feed conversion ratio (FCR) that has the most efficient production cost and highest ADG is a prime factor to determine the efficiency of animals production.

Goats naturally like foraging/browsing, if the quality of forages/browses is not good, thus the ADG will be low, and vice versa. The average daily body weight gain or average daily gain (ADG) and feed conversion ratio (FCR) of the kids fed with $\mathrm{T} 0, \mathrm{~T} 1$ and $\mathrm{T} 2$ treatment diets were presented in Table 5.

Table 5. The average values ( \pm SEM) of average daily gain (ADG) and feed conversion ratio (FCR) of the kids during the feeding trial

\begin{tabular}{lccc}
\hline \hline \multirow{2}{*}{ Variables } & \multicolumn{3}{c}{ Treatment Diets } \\
\cline { 2 - 4 } & \multicolumn{1}{c}{ T0 } & \multicolumn{1}{c}{ T1 } \\
\hline ADG (g/head/day) & $58.2^{\mathbf{a}} \pm 7.3$ & $85.7^{\mathbf{b}} \pm 11.5$ & $76.1^{\mathbf{b}} \pm 12.3$ \\
FCR & $25.6^{\mathbf{a}} \pm 6.3$ & $15.9^{\mathbf{b}} \pm 3.4$ & $18.0^{\mathbf{b}} \pm 2.0$ \\
\hline
\end{tabular}

$\mathrm{T} 0=0 \%$ rubber leaves and its branches $+80 \%$ other forages $+20 \%$ rice bran; $\mathrm{T} 1=40 \%$ rubber leaves and its branches $+40 \%$ other forages $+20 \%$ rice bran; $\mathrm{T} 2=60 \%$ rubber leaves and its branches $+20 \%$ other forages $+20 \%$ rice bran. Different superscripts in the same row showed significant differences $(\mathrm{P}<0.05)$; SEM: standar error means

The results of the statistical analysis showed that ADG of the kids in T0 treatment group was significantly $(\mathrm{P}<0.05)$ lower than those of $\mathrm{T} 1$ and $\mathrm{T} 2$ treatment groups, with no difference between the latter two groups. Based on DM, DE and DP consumption in all treatment groups, the lower $\mathrm{ADG}$ and $\mathrm{FCR}$ in $\mathrm{T} 0$ treatment group was attributed to significantly lower DP consumption when compared to T1 treatment group, and significant lower DE and DP when compared to T2 treatment group. However, an ADG of above $50 \mathrm{~g}$ in the T0 treatment group (Table 5), was probably due to the use of $20 \%$ rice bran in the diet which increase its energy content.

Based on the results of the study, it can be concluded that the use of rubber leaves and its branches in the diets can increase body weight gain and decrease FCR, and consequently increase the production efficiency of the goats.

\section{CONCLUSION}

The use of rubber leaves and its branches with composition of $40 \%$ to $60 \%$ of goat diets can increase energy and protein consumptions, increase body weight gain, decrease FCR, and subsequently increase the production efficiency of the goats. 


\section{REFERENCES}

AOAC. 2002. Official Method of Analysis. 12 th Ed. Washington DC (USA): Association of Official Analytical Chemist. p. 129-146.

Aregheore EM, Kumar A, Manueli P. 2003. Dietary levels of energy and protein for optimal growth of crossbred Anglo-Nubian goats in Samoa. Int J Agric Biol. 5:428-431.

Kearl LC. 1982. Nutrient Requirement of Ruminant in Developing Countries. InternasionalFeedstuff Institute Utah Agricultural Experiment Station. Logan (USA): Utah State University.

Makkar HPS. 2003. Effects and fate of tannins in ruminant animals, adaptation to tannins, and strategies to overcome detrimental effects of feeding tannin-rich feeds. Small Rum Res. 49:241-256.

Manu AE, Henuk YL, Belli HLL, Kleden MM. 2015. Supplementation local feed urea gula air multinutrient block and different Level of sulphur for increasing lactation productivity doe also decreasing kid mortality Bligon goat grazed at Timor savannah. In: Proceedings of the 6th ISTAP, International Seminar on Tropical Animal Production: Integrated Approach in Developing Sustainable Tropical Animal Production. Yogyakarta, 20-22 October, 2015. Yogyakarta (Indonesia): Gadjah Mada University. p. 133-137.

Mohsen MK, Gaafar HMA, Khalafalla MM, Shitta AA, Yousif AM. 2011. Effect of rumen protected choline supplementation on digestibility, rumen activity and milk yield in lactating Friesian cows. Slovak J Anim Sci. 81:238-242.

NRC. 1981. Nutrient Requirements of Goats: Angora, dairy and meat goats in temperate and tropical countries. Washington DC (USA): National Academy Press.

Paolini V, Bergeaud JP, Grisez C, Prevot F, Dorchies P, Hoste H. 2003. Effects of condensed tannins on goats experimentally infected with Haemonchus contortus. Vet Parasitol. 113:253-261.

Wigati S. 2010. Integrasi tatalaksana pemberian pakan cassava dan reproduksi untuk meningkatkan kinerja kambing Bligon [Disertation]. [Yogyakarta (Indonesia)]: Universitas Gadjah Mada.

Wigati S, Maksudi M, Latief A. 2014a. Analysis of rubber leaf (Hevea brasiliensis) potency as herbal nutrition for goats. In: Proceedings of the 16th AAAP Animal Science Conggress Vol. II. Yogyakarta, 10-14 November, 2014. Yogyakarta (Indonesia): Gadjah Mada University. p. 497-500.

Wigati S, Kustantinah, Wiyanto E, Ørskov ER. 2014b. In sacco degradability of six different tropical feedstuffs. In: Proceedings of the 16th AAAP Animal Science Conggress Vol. II. Yogyakarta, 10-14 November, 2014. Yogyakarta (Indonesia): Gadjah Mada University. p. 376-379.

Wigati S, Maksudi M, Latief A, Wiyanto E. 2015. Tannin anthelmintic doses, metabolizable energy and undegraded protein contents of rubber leaves (Hevea brasiliensis) as herbal nutrition for goats. In: Proceedings of the 6th ISTAP, International Seminar on Tropical Animal Production: Integrated Approach in Developing Sustainable Tropical Animal Production. Yogyakarta, 20-22 October, 2015. Yogyakarta (Indonesia): Gadjah Mada University.p. 151-155.

\section{DISCUSSION}

\section{Question}

Data initial BW varied, but variation of data consumption not so much, can you explain?

\section{Answer}

Data were analysed according to the design experiment 